Москалець С.В., Жирний В.А., Цілина С.В., Кузін С.Є., Живець Ю.М. Державний науководослідний інститут випробувань і сертифікації озброєння та військової техніки

\title{
ЗАХИСТ СУЧАСНИХ ВІТЧИЗНЯНИХ ТАНКІВ: ПОТОЧНИЙ СТАН, МОЖЛИВІ НАПРЯМИ РОЗВИТКУ
}

У даній статті висвітлені питання щуодо можливості та методів захисту танків та іншої бронетехніки, а також напрямки роботи з його удосконалення.

Ключові слова: методи захисту танків, захист від технічних засобів розвідки, проблеми ефективного захисту техніки.

\section{Вступ}

Постановка проблеми. Події, які останнім часом відбуваються на сході України, засвідчили, що технічне оснащення Збройних Сил України (ЗСУ) перебуває на низькому рівні.

Зразки озброєння та військової техніки (ОВТ) ЗСУ фізично та морально застаріли та не відповідають сучасним вимогам.

Значення танкових військ, як одного з головних родів сухопутних військ та їхньої головної ударної сили, збережеться і в майбутньому. Танкові війська, у силу своєї мобільності та бойової могутності, $є$ надійним гарантом забезпечення поставлених перед сухопутними угрупуваннями завдань на різних континентальних театрах воєнних дій.

Сьогодні розвиток протитанкових засобів знаходиться на такому рівні, що навіть потужний броньовий захист може бути здоланий відносно дешевими засобами ураження. Збільшення товщини броні себе вичерпало і не розв'яже існуючу проблему за тактикоексплуатаційними та економічними показниками.

\section{Виклад основного матеріалу}

Для вирішення проблеми ефективного захисту техніки на полі бою існує декілька напрямків.

Виживання основних бойових танків та бойових броньованих машин має зазвичай чотири основні аспекти: уникнення виявлення, уникнення попадання, уникнення пробиття броні, якщо броня пробита, уникнення катастрофічного ушкодження усередині машини.

Перший напрямок - уникнення виявлення, пов'язано головним чином 3 силуетом машини, загальною видимістю і “ознаками” як у видимому спектрі, так і в ІЧ-області спектру i спектрі частот радіолокації. У видимому спектрі застосовується спеціальне деформуюче забарвлення, маскувальне покриття, архітектура зразка, що знижує ефективне поверхневе розсіювання (ЕПР), теплове екранування даху силового відділення і ходової частини техніки, яке здатне дати задовільні результати відносно виявлення по ІЧ-випромінюванню, виявленню радіолокацією і відповідно значно зменшити відстань та імовірність виявлення танка засобами розвідки і наведення засобів ураження 3 голівками самонаведення високоточних боєприпасів [3].

Станом на сьогоднішні день - українські виробники та науковці інтенсивно працюють в напрямку захисту бронетанкової та іншої техніки від виявлення технічними засобами розвідки. Уже розроблене та проходить випробування спеціальне анти лазерне покриття у вигляді облицювальної плитки товщиною до 12 мм для робочого частотного діапазону 6-65 ГГц 3 коефіцієнтом відбиття електромагнітного випромінювання - (15-20) дБ та у вигляді багатошарового фарбованого покриття товщиною до 3,5 мм 3 коефіцієнтом відбиття електромагнітного випромінювання - (8-18) дБ для робочого частотного діапазону 8-120 ГГц. Передбачається можливість забезпечення на вказаних покриттях поглинання 
електромагнітного випромінювання в інфрачервоному діапазоні до -18 дБ в інтервалі довжин хвиль 0,9-1,54 мкм.

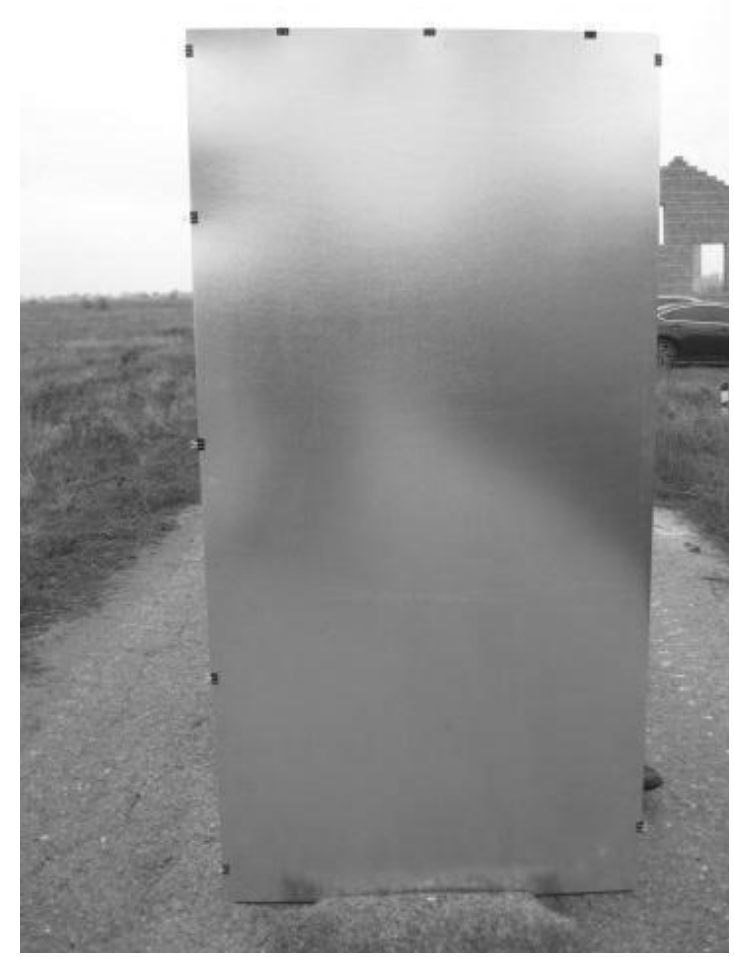

$\mathrm{a}$

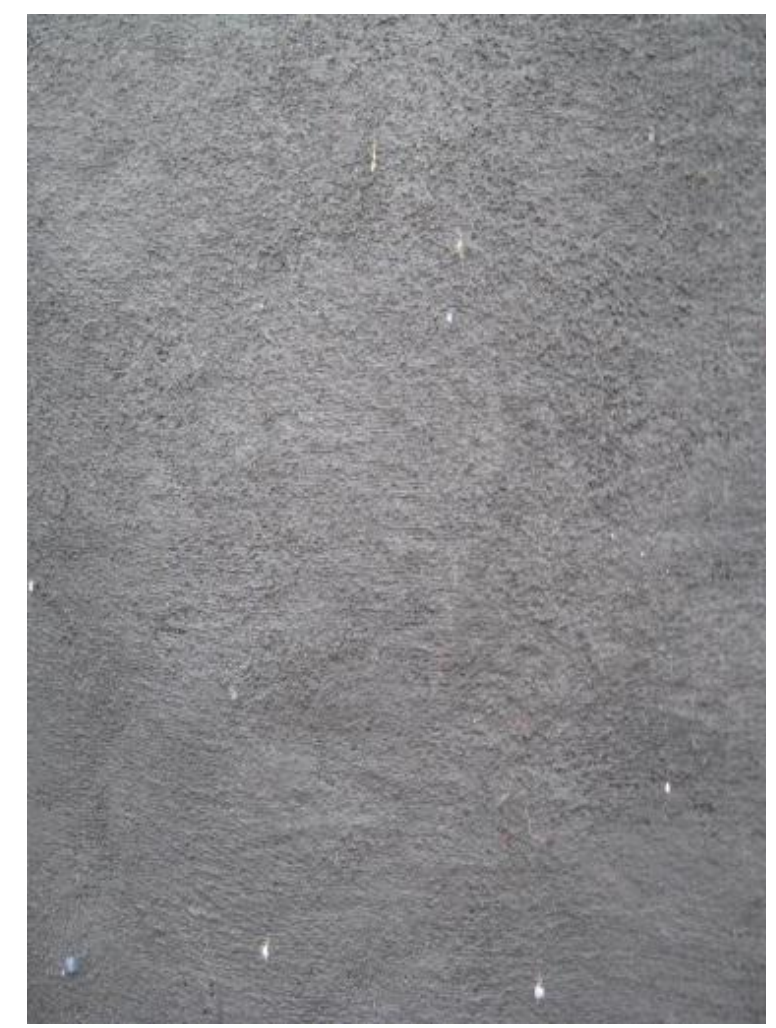

6

Рис. 1 - Металевий лист

а) без нанесення антирадарного покриття,

б) з нанесеним антирадарним покриттям.

Можливим напрямом може бути розробка комплексів, що включають постановник активних перешкод лазерним засобам далекометрування. Українські розробники вже створили вдосконалений комплекс "Варта" встановлений на танку “Оплот”, який забезпечує виявлення лазерного опромінення танка в межах $360^{\circ}$ в горизонтальній площині і $20^{\circ}$ по вертикальній. Точність визначення напряму на джерело опромінення передніми приймачами складає не менше $3^{\circ} 27^{\prime}$ в секторі 90. Дві точні голівки, встановлені в передній частині даху вежі, і дві грубі голівки, встановлені в кормовій частині даху вежі.

Другий напрямок - застосування тактичних прийомів на полі бою та комплексів активного захисту (КАЗ), тобто знищення (порушення траєкторії польоту) атакуючого боєприпасу при підльоті до цілі пучком вражаючих елементів. Особлива увага приділяється створенню нових та вдосконаленню існуючих КАЗ типу українського “Заслон”, прототипом якого є “Дождь” радянської розробки 70-х років. Але, це не було реалізовано в серійному використанні. Причиною цього стала концептуальна невизначеність у зв'язку 3 можливістю поразки елементами КАЗ своєї піхоти і легко броньованої техніки. Слід зазначити, що подібний недолік характерний для зарубіжних КАЗ типу MUSS (CША), AMAP ADS (Німеччина), “Тторhy” (Ізраїль) і інших. Також ведеться розробка КАЗ далекої дії SLID. Виявлення i визначення координат цілі здійснюється за допомогою ІЧ-пристрою міліметрового діапазону. Ураження цілі здійснюється малогабаритним керованим снарядом-перехоплювачем. Дальність ураження цілі снарядом SLID складає 100 м від броньованої машини, що захищається. Безумовно, КАЗ стане невід'ємною частиною бронетехніки [1]. 
Третій напрямок - оснащення бронетехніки різними захисними екранами i комплексами динамічного захисту (ДЗ).

Динамічний захист - це загальна назва захисного пристрою, принцип дії якого полягає в тому, що вмонтована між броньованих листів (пластин) речовина впливає на зниження ефективності пробивної здатності снаряду (ракети), шляхом поглинання частини його енергії.

Пристрої динамічного відрізняються між собою варіантами конструкції та використовуваними джерелами енергії. Речовина, що розміщується між листами, може бути вибуховою, не вибуховою та комбінованою в кілька шарів.

“Ніж” - модульний комплекс динамічного захисту третього покоління для танків українського виробництва. Призначений для захисту бойових машин та стаціонарних об'єктів від бронебійних снарядів, кумулятивних засобів ураження та ударно-кумулятивних боєприпасів типу “ударне ядро”.

“Дупле́т” - модульний комплекс тандемного динамічного захисту третього покоління для танків українського виробництва. Модернізована версія комлексу "Ніж”. Призначений для захисту бойових машин та стаціонарних об'єктів від артилерійських кумулятивних снарядів калібром до 125 мм та тандемних кумулятивних засобів ураження, ударно-кумулятивних боєприпасів типу “ударне ядро”, реактивних танкових гранат та цільнометалевих оперених бронебійних підкаліберних снарядів.

Елементи динамічного захисту можуть розміщуватися або в спеціальних броньованих контейнерах на зовнішній поверхні танка (навісний динамічний захист) або вмонтованими прямо всередині броньованих вузлів, тобто бути складовою частиною комбінованої броні (вбудований динамічний захист).

Перші досить ефективні проти існуючих кумулятивних снарядів i ручних протитанкових гранат. Другі у вигляді коробчастих елементів 3 невеликою кількістю вибухової речовини усередині, які служать для захисту танків від кумулятивних i бронебійних підкаліберних снарядів. При попаданні снаряду в ДЗ вони детонують i зустрічним вибухом протидіють вражаючим боєприпасам. Сучасні розробки в області динамічного захисту, що використовують для дії на боєприпас енергію вибуху, здатні підвищити базовий рівень захисту танку до двох разів. Також перспективним рішенням може бути застосування багатошарової, інтегрованої безпосередньо в масив бронювання на декількох рівнях динамічний захист, реалізований в якості знімних модулів.

Ще один напрямок припускає зниження наслідків заброневої дії на екіпаж і внутрішнє устаткування бронетанкової техніки - поразка екіпажу та внутрішнього устаткування осколками броні i снаряда за бронею, продуктами вибуху розривного заряду або кумулятивним струменем, які виникають при використанні бронебійних і кумулятивних артилерійських снарядів і касетних бойових елементів [2].

Часи “пасивноі” і навіть багатошарової броні осталися в минулому. У сучасних умовах тільки комплексний підхід 3 урахуванням основних чинників, що впливають на захист і живучість танків і інших броньованих цілей, може забезпечити їм необхідну бойову живучість.

Живучість танка і екіпажу - це габаритні розміри, використання перспективних матеріалів у поєднанні з новими компоновочними і конструктивними рішеннями корпусу та башти, оснащення комплексом оптико-електронної протидії у поєднанні 3 активним, динамічним й протимінним захистом ісистема колективного захисту.

\section{Висновки}

Таким чином, сьогодні провідні виробники танків працюють над створенням перспективних зразків бронетанкової техніки і продовжують модернізацію існуючого парку танків, приймаючи до уваги рівень технічної досконалості.

Проведений аналіз свідчить, що в Україні є науковий, технологічний та виробничий потенціали, які дають їй змогу розробляти й виробляти новітні зразки ОВТ з тактико- 
Збірник наукових пращь Державного науково-дослідного інституту випробувань і сертифікачії озброєння та військової техніки. 2019. Вип. № 2

ISSN 2706-7386

технічними характеристиками, які відповідають вимогам сучасності, а іноді навіть i майбутнього.

Водночас цей аналіз доводить, що, на жаль, на оснащення ЗСУ надходять лише окремі одиниці цих нових ОВТ. Основна причина - відсутність відповідного державного оборонного замовлення через брак коштів.

\section{СПИСОК ЛІТЕРАТУРИ}

1. Бабаржанян А.Х. Танки и танковые войска. / А.Х.Бабаржанян. -1970.

2. Вооружение сухопутних войск. Танки: сборник статей. - М, 1966.

3. The Schornsteinfeger Project. CIOS Report XXVI-24.

\section{Москалець Сергій Васильович}

начальник науково-дослідного управління Державного науково-дослідного інституту випробувань і сертифікації озброєння та військової техніки, Чернігів, Україна https://orcid.org/0000-0001-5996-6422 $+380936002513$

\section{Жирний Володимир Анатолійович}

начальник науково-дослідного відділу Державного науково-дослідного інституту випробувань і сертифікації озброєння та військової техніки, Чернігів, Україна https://orcid.org/0000-0003-1882-3008 +093-782-85-28

\section{Цілина Сергій Васильович}

начальник науково-дослідної лабораторії Державного науково-дослідного інституту випробувань i сертифікації озброєння та військової техніки, Чернігів, Україна https://orcid.org/0000-0002-1936-7166 0462-67-94-29

\section{Кузін Сергій Свгенович}

начальник науково-дослідної лабораторії Державного науково-дослідного інституту випробувань і сертифікації озброєння та військової техніки, Чернігів, Україна https://orcid.org/0000-0003-2562-7902 0462-67-94-29

\section{Живець Юрій Михайлович}

науковий співробітник Державного науково-дослідного інституту випробувань і сертифікації озброєння та військової техніки, Чернігів, Україна https://orcid.org/0000-0003-4465-8667 0462-67-94-29

\section{Sergii Moskalets}

Chief of Division of State Scientific Research Institute of Armament and Military Equipment Testing and Certification, Chernihiv, Ukraine https://orcid.org/0000-0001-5996-6422 $+380936002513$

\section{Volodymyr Zhyrnyi}

Chief of Section of State Scientific Research Institute of Armament and Military Equipment Testing and Certification, Chernihiv, Ukraine https://orcid.org/0000-0003-1882-3008 +093-782-85-28

\section{Sergii Tsilyna}

Chief of Laboratory of State Scientific Research Institute of Armament and Military Equipment Testing and Certification, Chernihiv, Ukraine https://orcid.org/0000-0002-1936-7166 0462-67-94-29

\section{Sergii Kuzin}

Chief of Laboratory of State Scientific Research Institute of Armament and Military Equipment Testing and Certification, Chernihiv, Ukraine https://orcid.org/0000-0003-2562-7902 0462-67-94-29

\section{Yurij Zhivetc}

Researcher of State Scientific Research Institute of Armament and Military Equipment Testing and Certification, Chernihiv, Ukraine https://orcid.org/0000-0003-4465-8667 0462-67-94-29 
Збірник наукових праць Державного науково-дослідного інституту випробувань і сертифікачії озброєння та військової техніки. 2019. Вип. № 2

\section{PROTECTION OF MODERN NATIONAL TANKS, CURRENT STATE, POSSIBLE DIRECTIONS FOR DEVELOPMENT \\ S. Moskalets, V. Zhyrnyi, S. Tsilyna, S. Kuzin, Y. Zhyvets}

To date, the development of antitank means is at the level where exist an urgent need to improve the ability to protect armoured vehicles, as well as a need of unification of the main samples of armament and military (special) equipment. The analysis of the current state and outlook for development of visibility reduction means proves that there is a necessity to determine the most expedient variants for visibility reduction of the samples of military equipment of the Armed Forces of Ukraine from radar and optical-electronic reconnaissance equipment with a substantiation of the general requirements for the visibility reduction means.

The abovementioned goal is achieved through the use of non-conventional materials in combination with new design layout and structural solutions of the tank hull and turret, equipping with a complex of opto-electronic countermeasures in combination with visibility reduction, active, dynamic and mine protection systems of collective protection. Nowdays, Ukrainian manufacturers and scientists are working intensively to protect armored vehicles and other equipment from being detected by technical reconnaissance equipment, continuing to modernize the existing fleet of armored vehicles, taking into account the level of technical excellence.

The article "Protection of modern national tanks, current state, possible directions for development" contains the information about existing directions of protection of armored vehicles and their development. The research results in this area should be used in the preparation of armored vehicles for combat employment.

Keywords: tank protection methods, countermeasures against technical reconnaissance equipment, problems of effective armament protection. 